\title{
DEVELOPMENT OF HUMAN MAMMARY GLAND - A PRENATAL STUDY.
}

Rachna Magotra, Shyama K. Razdan, Raj Rishi Sharma

1. Lecturer, Department of Anatomy, Government Medical College, Jammu.

2. Professor \& Ex. H.O.D, Department of Anatomy, Government Medical College, Jammu.

3. Consultant Surgeon, Department of Surgery, J \& K Health Services.

\section{CORRESPONDING AUTHOR}

Dr. Rachna Magotra,

737, Subash Nagar,

Jammu, India.

E-mail: drmagotrarachna@gmail.com

Ph: 00919419189969.

ABSTRACT: 44 fetuses of varying gestational ages, ranging from 33m.m C.R.L. to 270 m.m.C.R.L. (i.e. from 8 weeks to 32 weeks of intrauterine life) were studied to note the developmental sequence of mammary gland. Tissues were prepared for microtomy by Paraffin wax embedding method. Serial sections were stained by Haematoxylin \& Eosin (H \& E) and Masson's Trichome method(1). It was observed that the organ is subject to fluctuations in its development. In the present study the primary bud, secondary bud, \& tertiary bud formation is seen at 11 th week ,14th week \& $18^{\text {th }}$ week of gestation respectively .The canalization appeared at $20^{\text {th }}$ week of gestation. Variation is seen in the mode of canalization as well as in the time of start of canalization. In the present study an endeavour has been made to establish the time of appearance of mammary buds and their time of canalization.The observations are compared with the findings of other workers and discussed in the light of literature. Mammogenesis or development of mammary gland is of great importance for anatomists, surgeons, pathologists, physicians, obstetricians etc. A large number of developmental anomalies like amastia, athelia, polymastia, polythelia, etc are of interest to them which can be understood more if thorough understanding of development of mammary gland is there.

KEY WORDS: Mammary gland. Fetus. Mammogenesis.

INTRODUCTION: Mammary gland is a modified apocrine sweat gland and is a unique specialization of class Mammalia. It is as unique and complex as fingerprints. Despite its external presence, easy acceptability, and availability of effective screening procedures, diseases of breast are one of the common causes of morbidity and mortality in females.

With the advent of modern technology and equipment for diagnostic and therapeutic procedure in the field of medical science, it becomes imperative to have sound knowledge of developmental anatomy. Such is the importance of mammary gland that its absence is recorded in Bible(8:VIII) as the "Song of Solomon" as we have a little sister, and she hath no breast; what shall we do for our sister in the day she shall be spoken for?(2) Unlike most mammalian organs which develop embryonically with a more or less linear progression towards functional maturity, the mammary gland has a series of highly orchestrated transitions or switches \& has both linear \& cyclical growth phases(3) .This gland develops by epithelio-mesenchymal interaction and the first distinction which must be made is the differentiation of presumptive mammary epithelium from tissues which would otherwise form skin, hair follicles ,or other ectodermally derived structures. The development begins in the $6^{\text {th }}$ week of intrauterine life as an ectodermal thickening called as Milk line on the ventral surface of fetus in Pectoral region . 
Further development involves transition of Mammary line to Mammary crest , Mammary hillock \& Mammary bud. The Mammary bud formation is a critical stage in development of mammary gland. (4) The time of appearance of various stages in the development of mammary gland vary. There is a variation in the mode of canalization. Also, many anomalies are reported in the development of breast due to drifting of cells to another area.

MATERIAL AND METHODS: The study was conducted on 44 fetuses of crown rump length ( C.R.L) ranging from $33 \mathrm{~mm}$ C.R.L. to $270 \mathrm{~mm}$ C.R.L. Out of 44 fetuses collected 36 were female, 6 were male and sex of 2 fetuses could not be determined.(table-1) They were collected from the department of Gynaecology and Obstetrics of Govt Medical College Jammu and from Nursing homes in and around Jammu after the consent of parents following all ethical norms and clearances. None had any congenital malformation. Gestational age was determined according to crown Rump Length(C.R.L.)criterion as described by Hamilton Boyd and Mossman 1976(5).The breast bud and surrounding ellipse of nipple containing skin was excised along with underlying soft tissue. The tissue was fixed in $10 \%$ formal saline for $24 \mathrm{hrs}$. and then prepared for microtomy by the Paraffin wax embedding method Tissue blocks were serially sectioned to generate 7 micrometer thick sections using a Rotary microtome The sections after mounting were stained with H \& E \& Massons Trichome stain.(1)

OBSERVATIONS: It was observed that there were individual variations in the development of mammary gland.

At 33mm C.R.L. there is a thickening of epithelium into a hillock which appears as a dome of ectodermal cells growing into the mesenchyme.

At 43-80mm C.R.L. Primary bud formation is seen. Primary bud is a spherodial mass of epithelial cells connected by neck to overlying epithelium which consists of superficial periderm and deeper stratum germinativum resting on a definite basement membrane. Primary bud is surrounded by several concentric layers of fine collagen, fibroblasts and blood vessels with nucleated R.B.C.s (fig.1)

At $\mathbf{8 8 m m - 1 3 8 m m ~ C . R . L . ~ S e c o n d a r y ~ b u d d i n g ~ i s ~ e v i d e n t ~ a s ~ t h e ~ o u t l i n e ~ o f ~ t h e ~ a n l a g e ~ i s ~ n o t ~}$ regular. This is due to infolding of the basal membrane which gives the gland complex a rosette shaped appearance surrounding by concentric layers of collagen and interspersed fibroblasts. There is a gradual transition of compactness of fibrils and fibroblasts as we move to the periphery. Secondary buds have extended deep down to the dermis but not to the subcutaneous tissues (fig.2)

At 140-170mm C.R.L. Tertiary budding is seen which show a tendency to be present in groups There is rich vascularity in surrounding connective tissue which contains fibroblasts, collagen fibres and preadipocytes.

At 180-200mm C.R.L. Evidence of canalization is seen in the form of clear spaces or cavities at various places in the anlage. The lumina is better developed in terminal ducts(fig.3).The canalized ducts are lined by two layers of cuboidal epithelial cells.

At 206-270mm C.R.L. Canalisation is well marked and is seen at both the ends of anlage. The picture is like the histological picture of inactive adult mammary gland. The ducts seen are from different orders of branching of main ducts. Each duct is surrounded by a tissue of relatively cellular connective tissue about as thick as the duct is wide. The cellular connective tissue which surrounds the individual duct is confluent with each other. The ducts are lined by two layers of epithelial cells and bear a lumen to show presence of canalization. The mammary pit is seen on 
the surface (fig.4) .

DISCUSSION: The present study illustrates a sequential view of human mammary gland development under light microscopy Differentiation of nipple was seen at $8^{\text {th }}$ week of gestation. This was in accordance with Anderson R.R.(2000)(6) and Williams P.L.(2000)(7). The thickening of the epidermal cells in the form of hillock was seen in fetus of 33mm C.R.L. The same stage was described by Turner(1952)(8) as mammary crest. Rugh (1968)(9)designated this stage as the $1^{\text {st }}$ recognizable stage in the mouse and called it Mammary welts .A well developed mammary bud was seen at $17 \mathrm{mmC}$.R.L.(11 ${ }^{\mathrm{TH}}$ week) which was a typical bulb shaped primary bud as proposed by Lewis M.T.(2000)(3). Authors like Revis Don Jr.(2003)(10)and Valdes M.A.(1979)(11) have found it at $7^{\text {th }}$ and $9^{\text {th }}$ week of gestation respectively while Porter C. John(1974)(12) ,Corles Clark Edward(1976)(13) and Hurley W.L.(2004)(4)saw it at $8^{\text {th }}$ week of gestation. Secondary bud formation was seen at 14 th week of gestation. This was in accordance with Anderson R.R.(1974)(6)who saw them at 14wks. The transverse section of this stage showed branching of a rounded structure due to formation of deep clefts which were formed from infolding of basal layers. This was in accord to Karp G. et al (1981)(14).

Tertiary sprouts were seen at $18^{\text {th }}$ week of gestation as observed by Myers J.A.(1917b)(15) in female albino rats.In human beings they are called as branches of secondary sprouts. Canalisation appeared at $20^{\text {th }}$ week of gestation as seen by Revis Don R.

Jr.(2003)(10)\&,Salazar H. et al (1971)(16). Williams P.L.(2000)(7)saw it at $22^{\text {nd }}$ week of gestation. Canalisation appeared at the proximal or inner end as noticed by Hurley W.L.(2004)(4)This is not in agreement to Brouha L.(1905)(17) who noticed the appearance of lumen in the external portion of the ducts first.

The differentiation of the lining epithelium of the duct into two layers of cuboidal cells was seen at $5^{\text {th }}$ month of gestation but the myoepithelial cells could be recognized in foetus of $210 \mathrm{~mm}$ C.R.L. as seen by Kass Rena and others.(2004)(18)

Embryonic type of fat was seen during all stages of development. There was regular and dense arrangement of connective tissue in the form of collagen fibers and fibroblasts around the developing analage which is required for branching process to continue .A large number of blood vessels are present So interactions between epithelium and mesenchyme are required for organogenesis and cytogenesis to proceed as observed by Karp Gerald et.al (1981)(19). There is no sexual dimorphism as observed by Kellokumpu Lehtinen P.et.al (1986)(20). Variation in the size \& shape of the anlage on the two sides of the same fetus was seen in anlage of $180 \mathrm{~mm}$ C.R.L. fetus. Moreover the anlage of $180 \mathrm{~mm}$ C.R.L. fetus was more developed then $182 \mathrm{~mm}$ C.R.L. fetus. Variation was also seen in the mode of canalisation. No anomaly of fetal breast development was detected in the present study. Also there is no difference in the prenatal development of Mammary gland in male and female.

SUMMARY: The development of fetal mammary gland entails a process of growth, differentiation, secretory activity and regression. This process of fetal mammary development involves a complex mechanism of cell interaction and hormonal balance. The present study reveals the changes in the epithelium in each stage from $33 \mathrm{~mm}$ C.R.L.to $270 \mathrm{~mm}$ C.R.L.. The anomalies reported in the development of breasts due to drifting of the cells medially and laterally from the mammary line like polymastia, polythelia, athelia, supernumerary nipples were not seen in the study undertaken. Therefore from the present study one can conclude that major part of development of fetal mammary gland occurs during second trimester of 
pregnancy and continues until the last trimester of pregnancy. Also there is no difference in the prenatal development of male and female. Individual variation were seen in the development of mammary gland in accordance to Raubitschek (21) who wrote in the beginning of his work that probably no other organ is subject to such great fluctuation in the development, as the mammary gland.

\section{REFERENCES:}

1. Drury and Wallington, in 'Carleton's histological techniques'4th Edition Published by Oxford University press, (1967), $4^{\text {th }}$ Ed.,Pg. 129.

2. Hubert C: Etude Sur L'amastic thesis Paris (1907) A. Michalon cited by Bland. I. Kirby ; Romrell J. Lynn (2004) in congenital and acquired disturbances of breast development and growth

3. Lewis Michael. T. in " Homeobox Genes in Mammary Gland Development \& Neoplasia"in the article for breast cancer research Department of Physiology \& Biophysics Colorado (U.S.A.),(2000), at http://www.pubmed central gov/article fig. Parotid $=138770$

4. Hurley. W.L. in "Mammary Gland Growth \& development" Department of Animal Sciences University of Illinios ,(2004), at http://classes .aces.vivc.edu/Ansci 308/mam growth.html.

5. Hamilton Boyd And Mossman's in Text Book of Human Embryology, Published by Williams and Wilkins Company ,(1976), 4th .Ed.Pg. 177.

6. Anderson R.R. in Embryonic and foetal development of the mammary apparatus, Edited by B.L.Larson \& V.R.Smith New York Academic Press (1974),Vol 1, Pg. 3-40, .

7. Williams PI in Gray 's Anatomy ,38 $8^{\text {th }}$ Edition published by Churchill Livingstone (2000), Pg. 148

8. Turner C.W., in "The mammary gland .I. The anatomy of the udder of cattle of and domestic animals"(1952), Lucas. Bros. Pub. Columbia Missouri cited by Anderson R.R. in" Embryonic and foetal development of the mammary apparatus" (1974). Edited by B.L.Larson \& V.R. Smith, New York Academic Press , Vol. 1,Pg. 3-40.

9. Rugh R., in "The MOUSE: Its reproduction and development" (1968), Burgess Minneapolis, Minnesota cited by Anderson R.R. in "Embryonic and foetal development of the mammary apparatus"( 1974 ), Edited by B.L.Larson \& V.R. Smith New York Academic Press Vol. 1.Pg. 3-40.

10. Revis. Don. R. in Breast Embryology University of Florida College of Medicine (2003) at http://www. e .medicine.com/plastic/topic 214 h.t.m.l.

11. Valdes Marie A;Florida Dapens in "The Breast" chapter Histology of foetus and new born, (1979), published by Saunders Company, chapter 29 Pg. 503-511.

12. Porter John C, in Hormonal regulation of breast development and activity, (1974),The Journal of Investigative Dermatology; Vol 63;Pg. 85- 92.

13. Corless Clark Edwards in Pattens Human Embryology,(1976), Published by Mc Graw Hill Book Company Pg.162-164.

14. Karp Gerald; Berril N.J. in book "Development" $2^{\text {nd }}$ Ed. Published by Mc Graw Hill Book Company

15. Myers J.A. in "Studies of Mammary Gland" Institute of Anatomy University of Minnesota American Journal of Anatomy ,(1917 b), Vol-22; No.2 Pg.195-223

16. Salazar H;Tobon H;Josimovich J.B.in Developmental, gestational and post gestational modification of human breast Journal of clinical obstetrics and Gynaecology, (1975),Vol.-18.No. 2, Pg.113-125.

17. Brouha L in Recherches surless diverses Phases de Development et de l activite de le mamelle ,(1905), Arch. Biol; Vol. 21;pg 459-596 cited by Long A Charles in "The Origin And Evolution of Mammary Gland" Bioscience, Vol.-19, No.6, Pg. 519-523. 
18. Kass Rena; Mancino A.J;Rosen Bloom A.L;,Klimberg V.S;Bland K.J, in breast Physiology ,(2004), in the book Bland \& Copeland Vol. $13^{\text {rd }}$ Ed. Comprehensive management of benign \& malignant disorders Published by Saunders Company chapter 3 ,Pg. 43-59.

19. Karp Gerald; Berril N. J. in book 'Development' $2^{\text {nd }}$ Ed. Published by Mc Graw Hill book company

20. Kellokumpu-Lehtinen P., Johansson R.M., \& Pelliniemi L.J. Ultra structure of human foetal mammary gland "The Anatomical records" vol. 218 Pg. 66-72.

21. Raubitschek H.,(1904)Veber die Brustdrusen menschlicheri Neugenboren c Zeittsch f. Heilkund. Abth.f. pathol. Anatomic Heft 1.

Table - 1

\begin{tabular}{|c|c|c|c|c|}
\hline S. No. & C.R.L. in $\mathrm{mm}$ & Age in days & Male/Female & No.of cases \\
\hline 1 & 33 & 58 & - & 1 \\
\hline 2 & 43 & 65 & - & 1 \\
\hline 3 & 70 & 83 & $\mathrm{~F}$ & 2 \\
\hline 4 & 77 & 88 & $\mathrm{~F}$ & 1 \\
\hline 5 & 80 & 90 & $\mathrm{~F}$ & 1 \\
\hline 6 & 88 & 95 & $\mathrm{~F}$ & 1 \\
\hline 7 & 90 & 96 & $\mathrm{~F}$ & 1 \\
\hline 8 & 104 & 106 & $\mathrm{~F}$ & 1 \\
\hline 9 & 108 & 108 & $\mathrm{~F}$ & 1 \\
\hline 10 & 110 & 110 & $\mathrm{~F}$ & 3 \\
\hline 11 & 117 & 115 & $\mathrm{~F}$ & 2 \\
\hline 12 & 122 & 118 & $\mathrm{~F}$ & 1 \\
\hline 13 & 125 & 120 & $\mathrm{~F}$ & 1 \\
\hline 14 & 130 & 123 & $\mathrm{~F}$ & 2 \\
\hline 15 & 138 & 128 & 2-F, 1-M. & 3 \\
\hline 16 & 142 & 131 & $\mathrm{~F}$ & 2 \\
\hline 17 & 145 & 133 & 2-F, 1-M. & 3 \\
\hline 18 & 150 & 136 & $\mathrm{~F}$ & 2 \\
\hline 19 & 160 & 143 & $\mathrm{~F}$ & 1 \\
\hline 20 & 165 & 146 & $\mathrm{~F}$ & 1 \\
\hline 21 & 170 & 150 & $\mathrm{M}$ & 1 \\
\hline 22 & 175 & 153 & $\mathrm{~F}$ & 2 \\
\hline 23 & 180 & 156 & $\mathrm{~F}$ & 1 \\
\hline 24 & 182 & 158 & $\mathrm{~F}$ & 1 \\
\hline 25 & 185 & 160 & $\mathrm{~F}$ & 1 \\
\hline 26 & 190 & 163 & 1-F, 1-M. & 2 \\
\hline 27 & 206 & 174 & $\mathrm{M}$ & 1 \\
\hline 28 & 210 & 176 & $\mathrm{~F}$ & 2 \\
\hline 29 & 212 & 178 & $\mathrm{~F}$ & 1 \\
\hline 30 & 270 & 216 & M & 1 \\
\hline
\end{tabular}




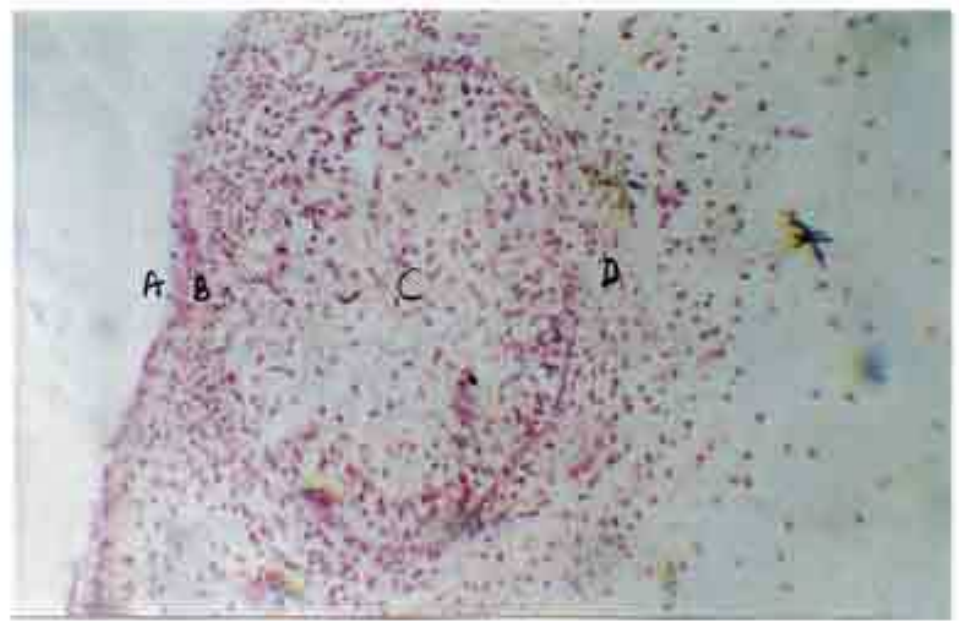

Fige 1-Mammary Pit(A), Neck(B) or Primary bud(C) and condensed mesenchyme (D)in $80 \mathrm{~mm}$, C.R. length foetus

$$
\mathrm{H} \& \mathrm{E} * 100
$$

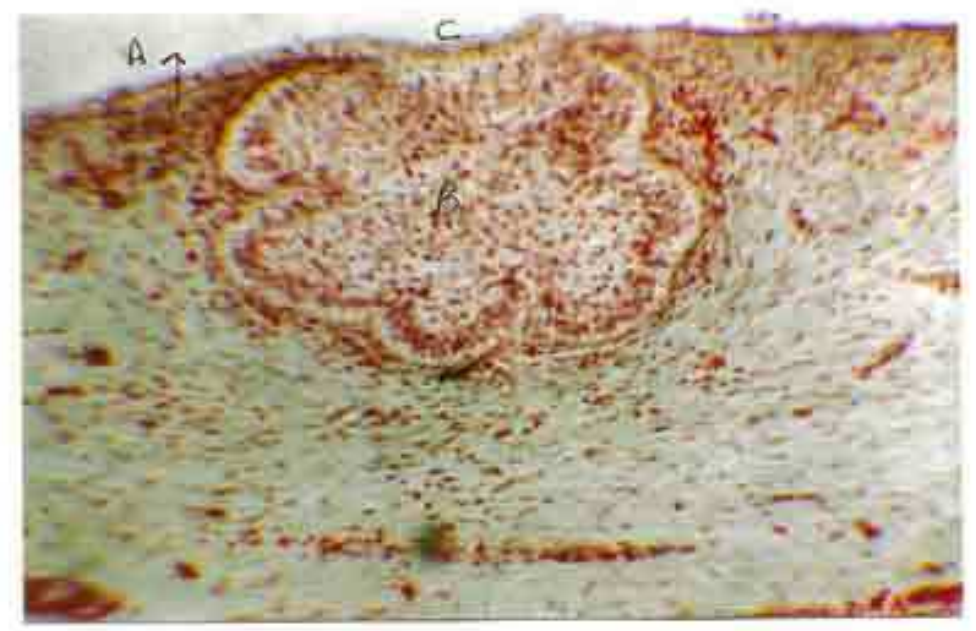

Fig. 2-Epidermis(A), Secondary bud(B) and Mammary pit(C) in $110 \mathrm{~mm}$. C.R. length Foetus Masson's Trichrome * 100 


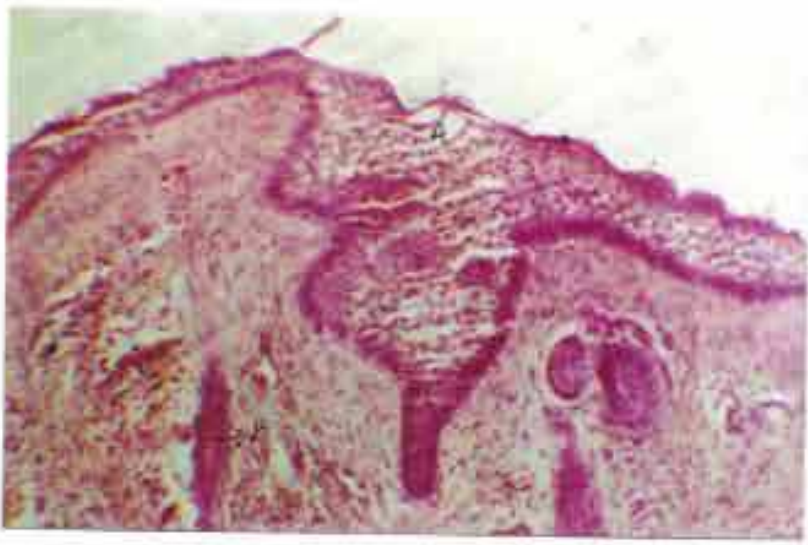

Fig. 3-Gap within the Arlage $(A)$, Lumen within the tertiary buds ( $B$ ) In $180 \mathrm{~mm} C \mathrm{C}$. length fetras

H. \& E. * 100

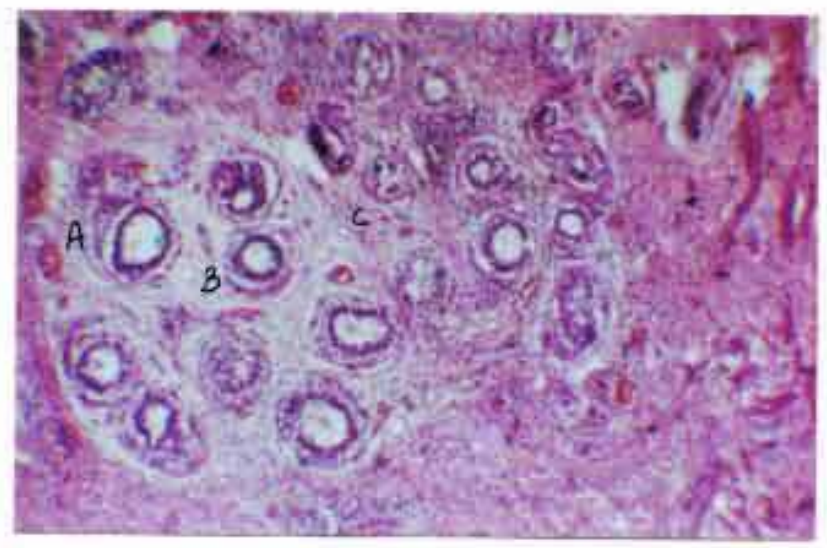

Fig. 4-Lobule formation by lerminal ducts (A), Interlobular connective tissue (B) and interlobulur connective tissue $(\mathrm{C})$ in

$210 \mathrm{~mm} \mathrm{C} \cdot \mathrm{R}$. length fetus

H. \& $* 100$ 